\title{
JILS
}

\section{UPAYA PUSTAKAWAN DALAM MENGATASI VANDALISME}

\section{STUDI KUALITATIF TENTANG UPAYA PUSTAKAWAN DALAM \\ MENGATASI PEROBEKAN BAHAN PUSTAKA OLEH SISWA KELAS III DI PERPUSTAKAAN SD NEGERI CILAKU KECAMATAN CIMANGGUNG KABUPATEN SUMEDANG}

\author{
Undang Sudarsana ${ }^{1}$ Novi Widya ${ }^{2}$ Emas $^{3}$ \\ 1 \\ Dosen Ilmu Perpustakaan dan Informasi, Universitas Islam Nusantara, Bandung \\ undangsudarsana@gmail.com \\ 2 \\ Dosen Ilmu Perpustakaan dan Informasi, Universitas Islam Nusantara, Bandung \\ novi.widya@uninus.ac.id \\ ${ }^{3}$ Mahasiswa, Ilmu Perpustakaan dan Informasi, Universitas Islam Nusantara, Bandung \\ emaemilia07@gmail.com
}

\begin{abstract}
Abstrak
Vandalisme di perpustakaan merupakan tindakan perusakan yang dilakukan oleh manusia terhadap koleksi maupun fasilitas yang ada di perpustakaan. Bentuk dari tindakan vandalisme terhadap bahan pustaka diantaranya corat coret, menandai dengan bolpoint atau stabilo, memberi tanda sebagai batas baca, melipat bahan pustaka, merobek, mengambil sebagian halaman bahan pustaka, menggunting gambar, mencopot stiker, penambahan tulisan serta mengotori bahan pustaka. Perpustakaan sekolah tidak terlepas dari bahaya vandalisme, salah satunya tindakan perobekan terhadap bahan pustaka. Hal yang dapat dilakukan pustakawan dalam mengatasi perobekan bahan pustaka yaitu dengan mengadakan kegiatan sosialisasi, melakukan kerjasama dengan guru kelas, melakukan kerjasama dengan orang tua siswa dan memberikan sanksi yang tegas terhadap pelaku perobekan bahan pustaka. Kata kunci: Pustakawan, vandalisme, perobekan bahan pustaka
\end{abstract}

\begin{abstract}
Vandalism in the library is an act of destcution committed by humans agains collection or facilities in the library. The form of vandalism against library materials such as scribbled marks, marked with ballpoint or highlighter, gave punctuation marks, forl library materials, rips, tore the page, removes stickers, attaches additives and contaminates library materials. The school library is inseparable from the dangers of vandalism, one of the act is tapping the materials. The things that librarians can do in overcoming library materials is by holding socialization activities, cooperating with teachers, parents and giving strict sanctions against the perpetrators of tapping library materials.
\end{abstract}

Keywords: librarian, vandalism, tapping library materials. 


\section{PENDAHULUAN}

Di tengah pesatnya perkembangan ilmu pengetahuan perpustakaan berperan dalam menyediakan berbagai sumber ilmu pengetahuan yang dibutuhkan melalui koleksi yang dimilikinya. Sesuai dengan fungsi dasarnya sebagai the preservation of knowledge, perpustakaan selayaknya mengusahakan secara maksimal untuk mengumpulkan, menyimpan, memelihara, serta menyebarluaskan segala jenis bahan pustaka yang berisi pengetahuan dan teknologi yang penting dan bermanfaat bagi masyarakat yang akan dilayaninya. Namun dalam pemanfaatannya tidak semua pemustaka mengikuti peraturan tata tertib yang berlaku di perpustakaan, hal ini dapat terlihat dari masih banyaknya ditemukan penyalahgunaan terhadap koleksi perpustakaan yang dilakukan oleh pemustaka diantaranya, bahan pustaka banyak yang dicorat coret, dirobek, diberi tanda, dikotori, ataupun hilang akibat tidak dikembalikan atau dicuri.

Vandalisme merupakan kerusakan atau penyalahgunaan bahan pustaka yang disebabkan oleh perbuatan manusia. Di dalam Kamus Besar Bahasa Indonesia (2003, 1116), istilah vandalisme diartikan sebagai "perbuatan merusak menghancurkan hasil karya seni dan barang berharga lainnya (keindahan alam dan sebagainya)". Vandalisme di perpustakaan merupakan kerusakan yang dilakukan oleh manusia yaitu pemustaka terhadap koleksi dan fasilitas yang ada di perpustakaan. Adapun perusakan yang dilakukan terhadap bahan pustaka diantaranya: corat coret, menandai dengan bolpoint atau stabilo, memberi tanda sebagai batas baca, melipat bahan pustaka, merobek, mengambil sebagian halaman bahan pustaka, menggunting gambar, mencopot stiker, penambahan tulisan serta mengotori bahan pustaka. Hal tersebut sesuai dengan pendapat Sulistyo-Basuki dalam Eka Efriza $(2015,46)$ menyatakan bahwa:

"Manusia dalam hal ini pemakai perpustakaan dapat merupakan lawan atau juga kawan. Pemakai perpustakaan menjadi kawan bilamana dia membantu pengamanan buku dengan cara menggunakan bahan pustaka secara cermat dan hati-hati. Pengunjung akan menjadi musuh bilamana dia memperlakukan buku dengan kasar, sehingga sobek atau rusak."

Perpustakaan sekolah tidak terlepas dari bahaya vandalisme, salah satunya adalah perpustakaan SD Negeri Cilaku Kecamatan Cimanggung Kabupaten Sumedang, hal ini dapat terlihat dari masih banyaknya koleksi perpustakaan seperti majalah, surat kabar, peta, koleksi fiksi serta koleksi lainnya yang sudah tidak lengkap lagi keadaan fisik maupun isi kandungan informasinya. Dari sekian 
banyak bentuk tindakan vandalisme yang

terjadi, perobekan bahan pustaka merupakan tindakan yang paling banyak ditemukan di perpustakaan tersebut. Dari hasil pengamatan di bagian layanan sirkulasi dan data kunjungan siswa, pelaku perobekan bahan pustaka sering dilakukan oleh siswa kelas III.

Perobekan bahan pustaka tentu saja menimbulkan kerugian yang sangat besar, Rahyuningsih dalam Eka Efriza (2015) mengatakan:

"Vandalisme dirasakan lebih banyak menghadirkan kerugian daripada keuntungannya. Akibat perobekan bahan pustaka koleksi perpustakaan menjadi berkurang sehingga dibutuhkan biaya yang tidak sedikit untuk memulihkan kembali kelengkapan koleksi perpustakaan".

Jika perobekan bahan pustaka dibiarkan terjadi secara terus menerus, kemungkinan besar perpustakaan tidak akan bisa memberikan pelayanan yang optimal kepada pemustaka sehingga fungsi dan tujuan perpustakaan tidak akan tercapai. Maka dari itu pustakawan harus mempunyai cara untuk mengatasi hal tersebut agar pemustaka sadar dan dapat memanfaatkan bahan pustaka dengan sebaik-baiknya sesuai dengan peraturan tata tertib yang berlaku di perpustakaan. Mengatasi perobekan bahan pustaka tentu saja bukan menjadi tanggung jawab pustakawan sendiri, namun pihak-pihak yang berada di lingkungan sekolah pun harus ikut bekerjasama, seperti kepala sekolah, guru dan orang tua siswa. Dengan adanya kerjasama antara berbagai pihak diharapkan dapat mempermudah dalam mengatasi dan mengurangi kerugian-

kerugian yang ditimbulkan. Adapun rumusan pada penelitian ini yakni bagaimana bentuk kegiatan yang dilakukan dalam mengatasi vandalism di perpustakaan SD Negeri Cilaku.

\section{TINJAUAN PUSTAKA}

Vandalisme di perpustakaan adalah pengrusakan yang dilakukan oleh manusia atau yang disebut pemustaka terhadap koleksi maupun fasilitas yang ada di perpustakaan. Menurut Kharismawan dalam Anggi Aprilia (2013) "vandalisme di perpustakaan adalah sebuah tindakan merusak atau perusakan barang-barang milik umum atau milik orang lain baik dengan cara penghapusan, penambahan, pengubahan maupun perusakan lainnya yang sengaja dilakukan”.

Salah satu bentuk vandalisme adalah perobekan pada halaman tertentu, hal ini sejalan dengan apa yang diungkapkan oleh Raabe dalam Eka Efriza (2015: 44) yang menyatakan bahwa "jika seseorang meminjam buku dari perpustakaan, kemudian membaca/melihat 
halaman menarik, kemudian tak tahan untuk memilikinya hingga merobek dan mengoyaknya, maka dia sudah jadi bibliocast atau sang penghancur buku”.

Jika kita membaca sebuah buku kemudian melihat halaman yang berisi gambar atau teks yang menarik perhatian secara sengaja ataupun tidak sengaja kita ingin memilikinya, kemudian secara langsung tanpa disadari bahwa buku itu bukan milik pribadi tetapi halaman tersebut harus dimiliki, maka timbulah perobekan terhadap bahan pustaka. Vandalisme merupakan hal serius yang segera harus ditangani oleh berbagai pihak di lingkungan sekolah, terutama pustakawan. Pustakawan harus berupaya untuk mengatasi dan meminimalisir tindakan tersebut agar kerusakan yang lebih hebat tidak terjadi. Serta menyadarkan siswa untuk selalu bersikap disiplin dan tanggung jawab dalam menggunakan dan memanfaatkan bahan pustaka dengan sebaik-baiknya.

\section{Upaya Mencegah Perobekan Bahan}

\section{Pustaka}

\section{Sosialisasi}

Pustakawan berharap agar koleksi perpustakaan bisa dimanfaatkan dengan sebaik-baiknya oleh pemustaka, namun pada kenyataannya masih banyak pemustaka yang tidak tau dan kurang faham mengenai ketentuan dan tata tertib yang berlaku di perpustakaan, sehingga hal tersebut mengakibatkan sebagian pemustaka melakukan pengrusakan terhadap bahan pustaka di perpustakaan khususnya tindakan perobekan bahan pustaka. Oleh karena itu salah satu tugas pustakawan adalah melakukan sosialisasi kepada pemustaka yaitu salah satunya dalam kegiatan pendidikan pemakai.

Menurut Lasa dalam Lisa Trinanda (2015: 18) menyatakan bahwa:

"Pendidikan pemustaka atau atau pemakai merupakan program yang diselenggarakan perpustakaan untuk memberikan bimbingan, petunjuk maupun pendidikan kepada calon pemustaka atau pemustaka perpustakaan dalam kegiatan mereka untuk memanfaatkan jasa informasi dan sarana yang ada di perpustakaan tersebut".

Sedangkan menurut Rice dan James dalam Lisa Trinanda (2015: 19) mengungkapkan bahwa dalam pendidikan pemustaka dapat memilih beberapa metode antara lain:

a. persentasi atau ceramah di kelas.

b. Wisata perpustakaan.

c. Penggunaan audio visual.

d. Permainan dan tugas mandiri.

e. Penggunaan buku pedoman atau pamflet.

Pustakawan melakukan sosialisasi kepada pemustaka tentang bagaimana cara memanfaatkan dan menggunakan bahan pustaka dengan sebaik-baiknya sehingga 
pemustaka mengetahui dan mengerti bagaimana dia seharusnya memperlakukan buku dengan baik dan benar. Dalam sosialisasi juga dibahas tentang tata tertib perpustakaan. dengan adanya sosialisasi akan menambah pengetahuan siswa tentang perpustakaan. Selain pustakawan sosialisasi juga dapat disampaikan oleh kepala sekolah dan guru kelas.

\section{Kerjasama}

\section{a. Kerjasama Pustakawan dengan Guru}

Menurut Laksmi dalam Selly Setiani (2016: 150) dari pandangan kontruktivis, kerjasama di definisikan "sebagai interaksi social antar individu atau kelompok yang secara bersama-sama untuk tujuan bersama". Sedangkan menurut Pamudji dalam Andi Prastowo (2013: 12-13) menjelaskan bahwa "kerjasama pada hakekatnya mengindikasikan adanya dua pihak atau lebih yang berinteraksi secara dinamis untuk mencapai suatu tujuan bersama".

Dengan adanya kerjasama diharapkan guru dan pustakawan dapat mengatasi dan meminimalisir perobekan bahan pustaka, baik itu di dalam gedung perpustakaan maupun saat didalam kelas. Melalui sikap moral yang diajarkan di dalam kelas melalui kegiatan belajar mengajar, diharapkan siswa mempunyai rasa tanggung jawab serta sikap disiplin dalam mengikuti semua peraturan tata tertib perpustakaan, sehingga dapat menggunakan bahan pustaka dengan sebaik-baiknya serta tidak melakukan kerusakan. Dengan demikian jika perobekan bahan pustaka dapat diatasi maka kerjasama guru, pustakawan dan kepala sekolah akan sesuai dengan tujuan yang diharapkan.

\section{b. Kerjasama Pustakawan dengan}

\section{Orang Tua Siswa}

Orang tua mempunyai peranan yang sangat penting dalam kehidupan siswa, dimana peranan orag tua harus mencakup seluruh aspek kehidupan siswa baik itu dilingkungan keluarga, sekolah, maupun di masyarakat. Peran orang tua juga dibutuhkan dalam membimbing siswa pada saat siswa meminjam bahan pustaka, karena bahan pustaka tidak hanya digunakan di perpustakaan atau di dalam kelas, namun bahan pustaka digunakan pemustaka saat dipinjam untuk dibaca dirumah.

Menurut Sinaga dalam Selly Setiani

(2016: 150) mengungkapkan bahwa:

"Dalam upaya memberikan pelayanan yang baik bagi para pengguna perpustakaan sekolah, maka perpustakaan harus mengadakan kerjasama dengan berbagai pihak diantaranya dengan Kepala Sekolah, guru-guru bidang 
studi, staf bimbingan dan penyuluhan serta orang tua murid".

Selanjutnya dia berpendapat bahwa bentuk kerjasama yang dilakukan adalah sebagai berikut:

a. Pembinaan koleksi perpustakaan sekolah, dimaksudkan agar segala koleksi yang ada dapat berdaya guna serta mampu memenuhi kebutuhan pemustaka dan tuntutan para pemakai perpustakaan.

b. Kerjasama dalam hal mempromosikan perpustakaan, kerjasama ini dapat dilakukan melalui penyampaian materi yang memungkinkan anak didik dapat mempergunakan berbagai macam sumber bahan pelajaran yang ada di perpustakaan sekolah.

c. Kerjasama tentang bimbingan dan cara optimalisasi pendayagunaan perpustakaan sekolah dalam proses belajar mengajar.

d. Kerjasama dalam upaya bimbingan minat baca antara pihak sekolah dan pihak orang tua murid sehingga adanya benang merah dan keseimbangan antara upaya yang dilakukan antara pihak sekolah dan orang tua dirumah.

e. Kerjasama dengan dewan sekolah dalam memenuhi kebutuhan fasilitas perpustakaan sekolah seperti gedung, rak buku, kursi baca, dan sebagainya. f. Kerjasama dengan para siswa terutama dalam membantu bagian sirkulasi dan dalam mengerjakan hal-hal yang bersifat administrative di perpustakaan.

Bentuk kerjasama pustakawan dan orang tua siswa dapat dilakukan pustakawan dengan memberikan sosialisasi kepada orang tua siswa tentang perpustakaan sekolah serta membimbing siswa dalam mengunakan bahan pustaka dirumah. Hal ini bertujuan agar orang tua siswa dapat ikut mengawasi dan membimbing penggunaan bahan pustaka pada saat dibaca dirumah. Orang tua dapat membimbing dan memberikan nasihat kepada siswa agar bahan pustaka tidak dirobek maupun dicorat coret, dan hal lain yang menyebabkan kerusakan, bahan pustaka harus selalu dalam keadaan bersih dan terawat saat dikembalikan ke perpustakaan.

\section{Sanksi bagi Pelaku Perobekan Bahan Pustaka}

Dalam kegiatan pelayanan perpustakaan, tentunya pustakawan sangat berharap agar koleksi perpustakaan dapat dimanfaatkan oleh pemustaka dengan sebaik-baiknya, namun pada kenyataannya masih banyak terjadi pelanggaran yang dilakukan oleh pemustaka salah satunya yaitu perobekan bahan pustaka. Tindakan tersebut tentu saja tidak sesuai dengan 
peraturan tata tertib perpustakaan yang berlaku. oleh karena itu apabila terjadi suatu pelanggaran sudah sepantasnya jika diberikan sanksi.

Menurut Kamus Umum Bahasa Indonesia dalam Listiyani (2010: 38) sanksi adalah "tindakan-tindakan, atau hukuman untuk memaksa orang menepati janji atau menaati apa-apa yang sudah ditentukan". Sanksi diberlakukan dengan tujuan untuk mendisiplinkan pemustaka agar melaksanakan dan mengikuti semua peraturan tata tertib perpustakaan. Adapun bentuk sanksinya yaitu berupa denda. Sedangkan denda menurut Kamus Umum Bahasa Indonesia (2001: 250) adalah "hukuman yang berupa keharusan membayar uang; uang yang harus dibayarkan sebagai hukuman karena melanggar aturan, undang-undang dan sebagainya".

\section{METODE PENELITIAN}

Penelitian ini menggunakan metode kualitatif dengan pendekatan deskriptif. Teknik pengumpulan data dilakukan dengan cara observasi, wawancara dan studi dokumentasi.

\section{PEMBAHASAN}

\section{Kegiatan Sosialisai dalam Mengatasi Perobekan Bahan Pustaka}

Sosialisasi adalah suatu kegiatan dimana ada satu atau beberapa orang yang berbicara di depan sejumlah peserta pada suatu waktu dan tempat tertentu mengenai suatu topik atau tema tertentu. Sosialisasi bertujuan untuk menyampaikan sesuatu yang ingin disampaikan oleh pembicara. Sosialisasi yang dilakukan pustakawan yaitu berbentuk pendidikan pemustaka dengan menggunakan metode ceramah. Materi ceramah secara umum berisi informasi tentang pelayanan yang ada di perpustakaan, selain itu ceramah yang disampaikan juga memberikan bimbingan dan pengarahan kepada siswa tentang cara menggunakan dan memanfaatkan bahan pustaka dengan baik dan benar sesuai dengan petunjuk dan peraturan tata tertib perpustakaan. Hal ini sejalan dengan yang diungkapkan oleh Lasa dalam Lisa Trinanda (2015: 18) menyatakan bahwa:

"Pendidikan pemustaka atau atau pemakai merupakan program yang diselenggarakan perpustakaan untuk memberikan bimbingan, petunjuk maupun pendidikan kepada calon pemustaka atau pemustaka perpustakaan dalam

kegiatan mereka untuk memanfaatkan jasa informasi dan sarana yang ada di perpustakaan tersebut". 
Pendidikan pemustaka di laksanankan pada awal masuk tahun pelajaran baru, bagi siswa baru kelas I, selain itu pendidikan pemaki juga disampaikan kepada seluruh siswa mulai dari kelas I sampai kelas VI. Setiap kelas dibuatkan jadwal dengan waktu yang berbeda dengan sepengetahuan kepala sekolah dan guru kelas.

Selain metode ceramah, sosialisasi juga dapat disampaikan dalam bentuk pamflet yang berisi ajakan kepada siswa untuk berhenti dan tidak melakukan kembali perobekan bahan pustaka, mengajak siswa untuk selalu menjaga dan merawat bahan pustaka supaya tetap terjaga kelestariannya. Pamflet dapat ditempel atau di simpan di mading perpustakaan, mading sekolah, maupun di tempat-tempat yang sekiranya tepat.

Hal tersebut diatas sejalan dengan yang diungkapkan oleh menurut Rice dan James dalam Lisa Trinanda (2015: 19) mengungkapkan bahwa dalam pendidikan pemustaka dapat memilih beberapa metode antara lain:
a. persentasi atau ceramah di kelas.
b. Wisata perpustakaan.
c. Penggunaan audio visual.
d. Permainan dan tugas mandiri.
e. Penggunaan buku pedoman atau pamflet.

Selain pustakawan sosialisasi juga disampaikan oleh kepala sekolah dan guru kelas III. Sosialisasi yang disampaikan baik itu berupa ceramah maupun pamflet akan membina dan mendidik moral siswa sehingga berpengaruh pada perubahan sikap dan tingkah laku kearah yang lebih baik. Dengan sosialisasi akan memberikan rasa saling pengertian antara berbagai pihak, baik itu pustakawan, kepala sekolah, guru dan siswa.

\section{Kerjasama Pustakawan dengan Guru Kelas III dalam mengatasi Perobekan Bahan Pustaka}

Selain pustakawan guru mempunyai tanggung jawab terhadap pengawasan bahan pustaka pada saat digunakan di dalam kelas. Oleh sebab itu pustakawan harus melakukan kerjasama dengan guru kelas III. Hal tersebut sesuai dengan yang diungkapkan oleh Laksmi dalam Selly Setiani (2016: 150) dari pandangan kontruktivis, kerjasama di definisikan "sebagai interaksi social antar individu atau kelompok yang secara bersama-sama untuk tujuan bersama". Sedangkan menurut Pamudji dalam Andi Prastowo (2013: 12-13) menjelaskan bahwa "kerjasama pada hakekatnya mengindikasikan adanya dua pihak atau lebih yang berinteraksi secara dinamis untuk mencapai suatu tujuan bersama”. 


\section{JILS}

Kerjasama antara pustakawan dan guru kelas III dapat dilakukan dengan cara pustakawan menyampaikan laporan rutin kepada guru tentang segala hal yang menyangkut pemanfaatan dan penggunaan bahan pustaka oleh siswa kelas III di perpustakaan, termasuk melaporkan tindakan perobekan bahan pustaka yang sering dilakukan oleh siswa kelas III. Dari hasil laporan tersebut guru dapat mengetahui berbagai hal seperti tingkat minat baca siswa kelas III di perpustakaan, siapa saja siswa yang rajin berkunjung ke perpustakaan, siapa saja siswa yang sering meminjam dan membaca buku ke perpustakaan, buku apa yang banyak digunakan oleh siswa, siapa saja siswa yang melakukan tindakan perobekan terhadap bahan pustaka, serta hal lain yang menyangkut dengan pemanfaatan perpustakaan.

Dari hasil laporan pustakawan kemudian guru menindak lanjuti seperti memberikan peringatan dan pengarahan kepada siswa pelaku perobekan bahan pustaka supaya tidak mengulang kembali perbuatannya. Jika dengan peringatan masih dapat belum mencegah atau mengurangi tindakan perobekan bahan pustaka, maka guru kelas akan memberikan sanksi yaitu berupa pengurangan nilai terhadap mata pelajaran PKN. Sedangkan bagi siswa yang bisa memanfaatkan dan menggunakan bahan pustaka dengan sebaik-baiknya akan diberikan nilai tambahan.

Kerjasama antara pustakawan dan guru dapat dilaksanakan dalam kegiatan pembelajaran di kelas, guru dapat memanfaatkan sebagian waktu pembelajaran untuk memberikan pembinaan dan bimbingan terhadap sikap moral siswa agar dapat menggunakan dan memanfaatkan bahan pustaka dengan sebaik-baiknya. Seperti memberitahu bagaimana cara merawat dan memelihara bahan pustaka agar tetap terjaga kelestariannya. Guru dapat menerapkan hal tersebut dalam mata pelajaran PKN yang berkaitan erat hubungannya dengan sikap disiplin dan tanggung jawab. Dengan demikian jika siswa sudah dibekali dengan sikap moral yang baik sejak dini, maka tindakan perobekan bahan pustaka dapat diatasi dan dihentikan supaya tidak terjadi kembali.

Hal tersebut diatas sejalan dengan yang diungkapkan Logan dalam Ina Royani (2017: 32) yang menyarankan kepada guru dan praktisi pustakawan untuk:

"Menangkap peluang kedepan dalam melakukan pendekatan terhadap guru kelas tentang konsep kolaborasi. Terlebih kolaborasi tersebut idealnya dilakukan pada 
saat guru melakukan pengajaran

kepada siswa mereka".

Dengan adanya kerjasama guru dan pustakawan, maka pengawasan dan pembinaan terhadap penggunaan bahan pustaka baik itu di perpustakaan maupun dikelas akan semakin meningkat. Dari kerjasama tersebut akan menimbulkan perubahan perilaku siswa baik dikelas maupun di perpustakaan, perubahan perilaku tersebut akan menumbuhkan kesadaran dari dalam diri siswa untuk selalu menjaga dan merawat bahan pustaka dengan sebaik-baiknya dimanapun bahan pustaka tersebut digunakan, siswa akan mejadi pemustaka yang disiplin dan bertanggung jawab dalam mematuhi dan mentaati segala peraturan tata tertib perpustakaan. Dengan demikian tindakan perobekan bahan pustaka dapat diatasi supaya tidak kembali terjadi. Jika koleksi perpustakaan terawat dengan baik maka kualitas layanan perpustakaan akan semakin baik pula, dan memberikan

kenyamanan bagi siswa dalam menggunakan bahan pustaka sehingga bahan pustaka dapat dimanfaatkan dengan sebaik-baiknya.

\section{Kerjasama Pustakawan dan Orang} Tua Siswa kelas III dalam Mengatasi

\section{Perobekan Bahan Pustaka}

$$
\text { Selain melakukan kerjasama }
$$
dengan guru kelas III, pustakawan SD
Negeri Cilaku juga mengadakan kerjasama dengan orang tua siswa kelas III dalam mencegah perobekan bahan pustaka. Hal tersebut dilakukan karena sebagian besar siswa melakukan perobekan pada saat bahan pustaka berada di lingkungan rumah. Oleh sebab itu orang tua siswa juga harus dilibatkan dalam pengawasan dan pembinaan penggunaan bahan pustaka. Hal tersebut sejalan dengan yang diungkapkan oleh Sinaga dalam Selly Setiani (2016: 150) yang menyatakan bahwa:

"Dalam upaya memberikan pelayanan yang baik bagi para pengguna perpustakaan sekolah, maka perpustakaan harus mengadakan kerjasama dengan berbagai pihak diantaranya dengan Kepala Sekolah, guru-guru bidang studi, staf bimbingan dan penyuluhan serta orang tua murid".

Selanjutnya dia berpendapat bahwa bentuk kerjasama yang dilakukan adalah sebagai berikut:

a. Pembinaan koleksi perpustakaan sekolah, dimaksudkan agar segala koleksi yang ada dapat berdaya guna serta mampu memenuhi kebutuhan pemustaka dan tuntutan para pemakai perpustakaan.

b. Kerjasama dalam hal mempromosikan perpustakaan, kerjasama ini dapat dilakukan melalui penyampaian materi yang memungkinkan anak didik dapat mempergunakan berbagai macam 


\section{JILS}

sumber bahan pelajaran yang ada di perpustakaan sekolah.

c. Kerjasama tentang bimbingan dan cara optimalisasi pendayagunaan perpustakaan sekolah dalam proses belajar mengajar.

d. Kerjasama dalam upaya bimbingan minat baca antara pihak sekolah dan pihak orang tua murid sehingga adanya benang merah dan keseimbangan antara upaya yang dilakukan antara pihak sekolah dan orang tua dirumah.

e. Kerjasama dengan dewan sekolah dalam memenuhi kebutuhan fasilitas perpustakaan sekolah seperti gedung, rak buku, kursi baca, dan sebagainya.

f. Kerjasama dengan para siswa terutama dalam membantu bagian sirkulasi dan dalam mengerjakan hal-hal yang bersifat administrative di perpustakaan.

Kerjasama dengan orang tua siswa kelas III dapat dilakukan pustakawan dengan mengadakan kegiatan pertemuan dengan orang tua siswa untuk memberikan sosialisasi tentang arti, fungsi, tugas dan manfaat perpustakaan sekolah dalam menunjang kegiatan belajar mengajar siswa disekolah. Orang tua diajak oleh pustakawan untuk bersama-sama saling membantu dalam mengawasi serta membimbing penggunaan dan pemanfaatan bahan pustaka dirumah.
Kerjasama antara pustakawan dan orang tua siswa dalam pengawasan bahan pustaka dapat berdampak pada kondisi koleksi perpustakaan, bahan pustaka akan tetap terawat dengan baik saat dikembalikan oleh siswa ke perpustakaan. Siswa akan lebih berhati-hati dalam menggunakan bahan pustaka karena ada bimbingan orang tua dirumah. Sehingga bahan pustaka dapat dimanfaatkan semaksimal mungkin oleh siswa meskipun berada diluar lingkungan sekolah.

\section{Sanksi Yang Diberikan Kepada} Pelaku Perobekan Bahan Pustaka

Selain memberlakukan tata tertib perpustakaan, perpustakaan SD Negeri Cilaku juga menerapkan saknsi bagi siapa saja yang melakukan pelanggaran terhadap tata tertib perpustakaan tersebut. Sanksi diberlakukan dengan tujuan untuk mendisiplinkan pemustaka agar melaksanakan dan mengikuti semua peraturan tata tertib perpustakaan. Menurut Kamus Umum Bahasa Indonesia dalam Listiyani (2010: 38) sanksi adalah "tindakan-tindakan atau hukuman untuk memaksa orang menepati janji atau mentaati apa-apa yang sudah ditentukan". Sanksi diberlakukan dengan tujuan untuk mendisiplinkan siswa agar melaksanakan dan mengikuti semua peraturan tata tertib perpustakaan. 
Perpustakaan SD Negeri Cilaku menerapkan dua sanksi bagi pelaku perobekan bahan pustaka, yaitu sanksi dalam bentuk denda dan sanksi dalam

bentuk pencabutan keanggotaan perpustakaan. Menurut Kamus Umum Bahasa Indonesia (2001: 250) adalah "hukuman yang berupa keharusan membayar uang; uang yang harus dibayarkan sebagai hukuman karena melanggar aturan, undang-undang dan sebagainya".

Denda bagi pelaku perobekan bahan pustaka yaitu berupa penggantian bahan pustaka yang dirusak atau dirobek dengan menggantinya seharga bahan pustaka yang rusak atau dirobek tersebut. Jika tidak berupa uang maka siswa harus menggantinya dengan buku yang sama, atau buku dengan judul lain yang bisa dimanfaatkan diperpustakaan. Denda diberlakukan bukan bertujuan untuk mengumpulkan uang atau keuntungan, tetapi denda diberlakukan untuk menjaga keutuhan bahan pustaka agar tetap lengkap kandungan informasinya dan terawat. Hasil dari denda digunakan pustakawan untuk mengganti atau menambah kembali koleksi yang rusak. Akan tetapi di perpustakaan SD Negeri Cilaku denda berupa penggantian dengan uang masih belum sepenuhnya bisa mengatasi perobekan bahan pustaka. Dengan alasan bagi yang mampu siswa masih sanggup membayar denda tersebut meskipun harus meminta uang tambahan kepada orang tua.

Sedangkan sanksi berupa pencabutan keangotaan perpustakaan diberlakukan kepada pelaku yang telah melakukan perobekan bahan pustaka sebanyak tiga kali berturut-turut maka keanggotaan perpustkaannya akan dicabut atau dikeluarkan dari keanggotaan perpustakaan. hal tersebut dilakukan jika pelaku perobekan bahan pustaka tidak bisa jera dengan peringatan dan denda.

Sanksi yang diberikan harus bersifat mendidik dan bukan untuk membuat siswa jera tidak kembali untuk memanfaatkan dan menggunakan segala fasilitas yang ada di perpustakaan, namun sanksi dibuat agar siswa disiplin dan bertanggung jawab dalam mematuhi segala peraturan tata tertib perpustakaan. pada dasarnya sanksi diberlakukan dengan tujuan untuk saling menguntungkan dan berbagi manfaat baik itu bagi pihak perpustakaan maupun pemustaka.

\section{KESIMPULAN}

Berdasarkan data-data hasil penelitian di Perpustakaan SD Negeri Cilaku Kecamatan Cimanggung Kabupaten Sumedang dan setelah diadakan 
pembahasan, maka peneliti dapat menarik

kesimpulan sebagai berikut:

1. Pendidikan pemustaka dan pamflet merupakan bentuk kegiatan sosialisasi yang dilakukan pustakawan SD Negeri Cilaku dalam mengatasi perobekan bahan pustaka. Sosialisai juga disampaikan oleh kepala sekolah dan guru. Pada umumnya materi sosialisasi yang disampaikan berisi pesan kepada siswa berupa bimbingan dan pengarahan tentang cara menggunakan bahan pustaka yang baik dan benar, sehingga bahan pustaka akan selalu terawat dan terjaga kelestariannya.

2. Kerjasama pustakawan dan guru dalam pengawasan dan pembinaan terhadap penggunaan bahan pustaka baik itu di perpustakaan maupun dikelas akan semakinmeningkat.Pustakawan menyampaikan laporan tentang pemanfaatan dan penggunaan bahan pustaka oleh siswa kelas III di perpustakaan, sehingga guru dapat menindak lanjuti setiap tindakan atau kegiatan yang dilakukan siswa kelas III di perpustakaan, termasuk menindak siswa pelaku perobekan bahan pustaka di dalam kelas dengan memberikan peringatan dan pembinaan. Dari kerjasama tersebut berdampak pada perubahan perilaku dan prestasi siswa di dalam kelas maupun di perpustakaan. Perubahan perilaku tersebut, yaitu timbulnya kesadaran siswa untuk selalu mematuhi dan mentaati segala peraturan tata tertib perpustakaan dengan demikian siswa menjadi pemustaka yang disiplin dan bertanggung jawab, sehingga kerusakan akibat perobekan bahan pustaka dapat teratasi.

3. Kerjasama antara pustakawan dan orang tua siswa dalam pengawasan bahan pustaka dapat berdampak pada kondisi koleksi perpustakaan, bahan pustaka akan tetap dalam keadaan terawat dengan baik saat dikembalikan oleh siswa ke perpustakaan. Siswa akan lebih berhati-hati dalam menggunakan bahan pustaka, sehingga bahan pustaka dapat dimanfaatkan semaksimal mungkin oleh siswa meskipun digunakan diluar lingkungan sekolah.

4. Perpustakaan SD Negeri Cilaku menerapkan dua sanksi bagi pelaku perobekan bahan pustaka, yaitu sanksi dalam bentuk denda dan sanksi dalam bentuk pencabutan keanggotaan perpustakaan. Sanksi berupa pencabutan keanggotaan diberlakukan bagi siswa yang telah melakukan tindakan perobekan bahan pustaka sebanyak tiga kali berturut-turut. Saksi berupa pencabutan keanggotaan dapat membuat 
jera pelaku perobekan bahan pustaka, akan tetapi bukan jera untuk tidak kembali menggunakan fasilitas perpustakaan namun sanksi harus bersifat mendidik dan mengarah pada kebaikan dalam rangka perbaikan pelayanan perpustakaan.

\section{DAFTAR PUSTAKA}

Aprilia, Anggi. dan Sumaryanto, Yohanes. 2013. Penyalahgunaan dan Vandalisme Terhadap Koleksi: Studi Kasus di Perpustakaan Daerah Provinsi DKI Jakarta. Skripsi. Jakarta : Universitas Indonesia. http://lib.ui.ac.id/naskahringkas/201603/S46127-Anggi\%20Aprilia Diakses pada 08 Desember 2017 pada pukul 21.45

Efriza, Eka., dkk. 2015. Strategi Manajemen Perpustakaan Dalam menghadapi Vandalisme. Jurnal Kajian Informasi dan Perpustakaan. Vol.3, No.1, Juni 2015, hal. 43-70. http://jurnal.unpad.ac.id/jkip/article/do wnload/9488/4706 Diakses pada 19 September 2017 pukul 23.00
Listiyani. 2010. Penyalahgunaan Koleksi Perpustakaan. Skripsi. Jakarta : Fakultas Ilmu Budaya Universitas Indonesia.

http://lib.ui.ac.id/file?file=digital/2016 0877-RB13L199p-

Penyalahgunaan\%20koleksi.pdf.

Diakses pada 10 September pukul 17.00

Prastowo, Andi. 2013. Manajemen Perpustakaan Sekolah Profesional. Cetakan II. Yogyakarta: DIVA Press.

Setiani, Selly., dan Silvana, Hana. 2016. Kerjasama Antara Guru dengan Pustakawan dalam Layanan Perpustakaan Sekolah Dasar Hikmah Teladan. Ejournal UPI. Vol. 6 No. 2. http://ejournal.upi.edu/index.php/eduli b/article/view/5026 Diakses pada 07 Desember 2017 pukul 20.15

Trinanda, Lisa. dan Marlini. 2015. Pelaksanaan Pendidikan Pemakai di Perpustakaan Universitas Negeri Padang. Jurnal Ilmu Informasi dan Kearsipan. Vol.4, No. 1, September 2015, Seri A. http://ejournal.unp.ac.id/index.php/ii pk/article/viewFile/5141/4038 Diakses pada 5 Maret 2017 pukul 20.00 